\title{
Leadership Emergence in Post-Genocide Rwanda: The role of Women in Peacebuilding
}

\author{
David Mwambari*
}

\begin{abstract}
In the last two decades following the 1994 genocide Rwanda has been praised internationally for its strong leadership and revamped governance structures. This has resulted in rapid economic development, restorative justice, homegrown peacebuilding approaches, the tackling of corruption, and restoring security in a country that some analysts had prematurely depicted a hopeless case in state failure. In particular, promotion of women's rights has become a cornerstone of the Rwandan success story, but few scholars have examined the women who participated in this process and their positive contribution in rebuilding their communities. This article focuses on the role a small group of female leaders at different levels of society played in creating and fostering peacebuilding initiatives over the past two decades. It relies on secondary sources and the author's observations of several processes in the Rwandan society for more than a decade. It focuses on constructive steps taken in Rwandan society to promote women's leadership, which sets it apart from many other post-conflict countries while being aware of legitimate critiques of post-genocide Rwandan conditions.
\end{abstract}

\section{Introduction}

Immediately after the 1994 genocide the new government of national unity, made of members of Rwandan Patriotic Front (RPF) and pre-genocide opposition parties, started to rebuild Rwanda with the support of aid from Western countries. Rwanda stands out as a case study of a post-conflict country that is undergoing a promising economic recovery, despite criticism of its human rights record from dissidents, western human rights activists and some scholars. Although scholars question the effect of gender policies especially in rural areas, evidence shows that women contributed to Rwanda's peacebuilding process. This article focuses on the participation of individual women peacebuilders in Rwanda and their contribution as individuals or through civil society. First, the paper examines Rwanda's situation immediately after the genocide with reference to debates on women and their relevance in peacebuilding. Second, it discusses key events that preceded official national consultations in 1998 and 1999, and their effect on Rwandan women's situations after the genocide. Third, the paper reveals the outcomes of these conversations, which included the 2003 constitution, the Vision 2020 development initiative, promotion of women's leadership and peacebuilding initiatives. Lastly, it assesses what the Rwandan peacebuilding process reveals 
about the connection between governance and potential local conflict resolution solutions in post-conflict societies in Africa. The paper demonstrates that some women advanced from leadership positions at local levels to becoming important political figures at the national level. Furthermore, it shows that much of women's leadership in peacebuilding emerged at different levels of society concurrently as long as they adhered to Rwandan Patriotic Front's (RPF)'s political agenda.

\section{The 1994 genocide and its aftermath}

The 1994 Genocide against the Tutsi or the Rwandan Genocide claimed the lives of over eight hundred thousand to one million civilians, over eight hundred thousand to one million civilians, a majority of whom were Tutsi but including minority moderate Hutu also killed. Although the exact number of women raped and taken into sexual slavery during this period will never be known, survivor testimonies reveal that approximately 250,000 women were either gang or individually raped during the genocide, and an estimated $60 \%$ of them contracted HIV/AIDs. ${ }^{1}$ The killers had mainly targeted Tutsi women for rape, often after killing their husbands. ${ }^{2}$ Equally, Hutu and some Twa women had also lost their husbands in the 1990s and in killings that followed the genocide. Beyond that, Hutu women suffered social exclusion and public shame due to their individual roles or their husband's suspected roles in the massacres. ${ }^{3}$ Hutu, Twa and Tutsi women also lost their loved ones in the civil war before the genocide and other atrocities in its aftermath. ${ }^{4}$ Hence Rwandan women, like the rest of the Rwandan society, were divided along ethnic, class and geographic lines. But they also faced similar patriarchal barriers that included restrictive inheritance laws, extreme poverty, and insecurity of their lives and those of their families, domestic violence, as well as individual and collective trauma. ${ }^{5}$

In the aftermath of the genocide, widespread violence continued in different regions in Rwanda and Rwandans suffered the consequences of the disintegration of society. During the years from 1995 to 2000, Rwandans lived in a state of insecurity, fear, isolated revenge killings, detentions of individuals suspected of the genocide, insurgency in the North and uncounted conflicts over property ownership involving refugees and returning diaspora. Women also faced unique

\footnotetext{
${ }^{1}$ Newbury, Catharine and Hannah Baldwin(2001), 'Confronting the Aftermath of Conflict: Women's Organizations in Post-Genocide Rwanda', Women and Civil War: Impact, Organizations and Action pp.97-129.

2 See: Sharlach, Lisa (1999), 'Gender and genocide in Rwanda: Women as agents and objects of Genocide 1', Journal of Genocide Research 1(3), pp. 387-399.

${ }^{3}$ Burnet, Jennie E. (2012), Genocide lives in us: Women, Memory, and Silence in Rwanda (University of Wisconsin Press), pp.110-127

${ }^{4}$ Ibid pp. $12-13$

${ }^{5}$ op. cit. 13.
} 
challenges like domestic violence and rape. Like other post-war societies, the early stages of Rwanda's reconstruction were chaotic and lawless. The full consequences of the genocide were slowly becoming a reality in society.

In addition to a high number of fatalities, the members of previous governments and majority non-combatant Hutu men and women fled to neighboring countries in the millions. Others were internally displaced in different regions of Rwanda immediately after Rwandan Patriotic Army's (RPA) victory. ${ }^{6}$ Suspected individuals, mostly Hutu men, were imprisoned or killed and on occasion executed by RPA troops during the chaotic period preceding its victory. Thus, the number of Rwandan men dead, exiled or imprisoned surpassed that of women. Consequently, the population of women was disproportionately higher than that of men countrywide. In some parts of the country, it was estimated that up to $70 \%$ of the population were women. ${ }^{7}$ Some studies also projected that women-headed households were at $34 \%$ after the genocide compared to $25 \%$ before the genocide and the majority of these women were poor. ${ }^{8}$ Therefore post-genocide realities left most responsibilities to women in households and in communities.

A small cohort of women leaders rose to the occasion and took their place in shaping their new families, communities and society. They became 'agents of reconstruction' in post-genocide Rwanda. ${ }^{9}$ They emerged in an organic process to solve and engage with social and political challenges that were previously generally perceived as men's. Although some members of the new government frustrated some of the women's work or peace agenda, the majority of new government leaders were open to females in leadership as long as they adhered to RPF's vision. In fact, there were men in RPF who acted 'as conduits to further women's interests'10 especially in lobbying for change of laws in parliament. Hence, women's issues became central to the formulation of new laws and their voices were influential in shaping the peacebuilding agenda. However, in order to accomplish this, women to some extent broke cultural taboos and to a certain extent transformed the perception of women in the Rwandan society. ${ }^{11}$

\footnotetext{
${ }^{6}$ Rwanda Patriotic Army (RPA) was the army wing of Rwandan Patriotic Front (RPF).

${ }^{7}$ El- Bushra, Judy and Mukarubuga, Cecile (1995), 'Women, War and Transition', Gender and development 3 (3), pp. 16-22.

${ }^{8}$ Macauley, Cameron (Spring 2013), 'Women after the Rwandan Genocide: Making the Most of Survival.' James Madison University's Center for International Stabilization and Recovery. The Journal of ERW and Mine Action, 35

${ }^{9}$ Mageza-Barthel, Rirhandu (2015), Mobilizing transnational gender politics in post-genocide Rwanda (Ashgate Publishing Ltd) p.94.

$10 \mathrm{Ibid}$, p. 95 .

${ }^{11}$ Ibid
} 
Researchers have argued that 'successful and sustained development depends crucially on whether and how various leaders and elites within and across the public and private domains are able to form sufficiently inclusive 'developmental coalitions', formal or informal'.12 In order for the Rwandan Patriotic Front (RPF) to establish its influence and legitimacy on the Rwandan society it recognized the importance of building coalitions with pre-genocide political parties. Thus, the national assembly created the Government of National Unity in 1995 and started generating a peace agenda. ${ }^{13}$ The new elites embarked on a process to initiate and shape laws that reflected the conversations that were taking place nationally. ${ }^{14}$ Mageza-Barthel has also argued that the post-genocide government (through its Ministry of Gender) created its development and peace agenda in line with gender equality and international norms. ${ }^{15}$ She further argues that it wanted to differentiate itself from the pre-genocide governments that frustrated women participation in politics and become a 'participatory and representative democracy."16 Hence, the new government also included a large number of women, which reflected the reality of the new Rwandan society. Local leaders emerged as part of the process of achieving common goals with society; new peacebuilding initiatives were fostered to respond to unique context faced by Rwandans.

\section{Key goals sought by Rwandan society}

As Belgian colonial rule declined in the lead-up to Rwandan independence in 1962, a conversation started among Rwandans on what kind of a state the postindependence society envisioned. Disagreements on the questions of identity, political power, regional politics and leadership, as well as economic and social issues, intensified under Presidents Gregoire Kayibanda and Juvénal Habyarimana, and the short-term Dominique Mbonyumutwa and Théodore Sindikubwabo-led governments. During the post-independence period after 1962 well into the mid-1970s, minority Tutsi were attacked, killed or exiled into neighboring countries. The descendants of those who had been exiled were later to return in 1990 as RPA. A culmination of these tensions, as well as failed international interventions such as the 1990s United Nations sponsored Arusha talks, resulted in the genocide and other crimes in 1994.

\footnotetext{
${ }^{12}$ Leftwich, Adrian (2009) 'Bringing agency back in: politics and human agency in building institutions and states.' Synthesis and Overview Report of Phase One of The Leaders, Elites and Coalitions Research Programme, Research Paper 6, p. 10

${ }_{13}$ Prunier, Gérard (1995), The Rwanda crisis: History of a Genocide (Columbia University Press) pp. $127-130$

${ }^{14}$ Ibid

15 Mageza-Barthel (2015), p. 93

${ }^{16}$ Ibid, p. 66
} 
The genocide and killings of the 1990s traumatized generations of Rwandans. Hence, even before the 1998-1999 National Summits that drafted the famous 'Vision 2020', a document that gave a vision and road map to transform Rwandan society into knowledge-based economy, a resurrected intense national conversation took pace. Yet, as the ordinary citizen and leaders engaged in debates about the past, present, and future, the exchanges turned occasionally violent and a general lack of vision and unified goal was once again obvious.

In May 1998 and March 1999, consultative discussions were held at the then President Pasteur Bizimungu's office to discuss the challenges that Rwanda faced and to find a way forward. ${ }^{17}$ These forums included political elites and representatives of ordinary Rwandans from every tier of society including women representatives. ${ }^{18}$ As a result of this process, which included debates and discussions, the government established key goals by creating the comprehensive aspirational 'Vision 2020' document. This document would provide a direction out of poverty to Rwandan society. Laws based on a new constitution established by a national referendum in 2003 further protected these goals. Among such laws were the promotion of women's rights, and the validation of their place in leadership of the Rwandan society at all levels. ${ }^{19}$ The motivation was to include Rwandan women in leadership positions as equal to men. This change also aimed to change women's lives as the country transformed.

Furthermore, there was emphasis on adoption of local solutions that included indigenous peacebuilding mechanisms from the Rwandan culture. Consequently, the constitution reserved a 30\% gender quota of elected positions at all levels of national and local leadership to women representatives. ${ }^{20}$ Given the significantly higher number of women compared to that of men in the new society and given women's activism at different levels of society, the consultative talks included a number of women participants such as RPF's female leader Aloys Inyumba. Their participation was aimed at correcting previous laws that restricted women's freedom, and to uplift their place in society.

This marked a shift in gender roles. Previous Rwandan laws had restricted women from working or owning businesses without their husbands' approval. But now husbands encouraged their wives to own a business, men generally supported their female siblings to get employed as it benefited the entire family. ${ }^{21}$ However,

\footnotetext{
${ }^{17}$ Kotter, John P. (2015) 'What leaders really do', Harvard Business Review, 79(11), pp. 85-98.5.

18 Mutamba, John and Izabiliza, Jeanne (2007), 'The Role of Women in Reconciliation and Peace

Building in Rwanda Ten Years after Genocide: 1994-2004; Contributions, Challenges and Way

Forward.' JENda: A Journal of Culture and African Women Studies 10, p. 11

${ }^{19}$ Burnet (2012), pp.12-13.

${ }^{20}$ Rwandan Constitution (2003)

${ }^{21}$ Burnet (2012), p. 66
} 
widows in rural areas especially had difficulty in this newfound freedom with low productivity in their farms due to reduced male labour assistance. Thus women were forced to unite into cooperatives to maximize their labour collectively. These cooperatives became influential while individual women such as activist Judith Kanakuze, a Member of Parliament and within RPF leadership, and Aloys Inyumba, a long term RPF member and cadre, advocated purposefully for the new laws to factor in women's issues. Inyumba, Kanakuze and other women participants ensured that gender was a 'cross-cutting issue in 'Vision 2020' and in the mid-term implementation plan titled 'Economic Development and Poverty Reduction Strategy 2007-2012'.22

\section{Emergence of women leaders in the national peacebuilding process}

Women leaders emerged out of a divided society. They confronted the individual and collective challenges that divided Rwandans. As a snapshot of this divided society there were Hutu women who were suspects or whose husbands were condemned or imprisoned, as well as those who returned from Zaire abandoning their families in exile. There were Tutsi women whose husbands had been jailed for genocide crimes and faced social exclusion and genocide widows who included survivors of rape and those raising children orphaned by the atrocities. There were those who faced various challenges as either mixed ethnicities or returnees and those in Twa communities who were largely invisible. In addition, a majority of these women, regardless of their belonging, were rural and historically marginalized. Some had experienced some form of oppression and extreme poverty since their childhood. Thus it required immense courage from emerging women leaders among them to rise to local and national leadership and face multilayered social challenges, and build peace.

Leadership clusters engaged in peacebuilding activities emerged that can be grouped into three categories. Namely, women who were organized through civil society, those who were involved through informal networks, and the national policy makers. Among these groups individual female leaders were instrumental in creating not only peace agendas but also influencing outcomes that had longterm effects on the broader society.

\section{a. Civil Society}

One of the earliest organizations to engage women issues in Rwanda was the national umbrella organization Pro-femme/Twese Hamwe. Pro-femmes brought

\footnotetext{
22 Pamela, Abbott and Marklin, Rucogoza (2011), Legal and Policy Framework for Gender Equality and the Empowerment of Women in Rwanda, Institute of Policy Analysis and Research Rwanda, p. 5
} 
together about 60 women organizations. It had the ability to mobilize ordinary women in rural areas as well as the elites in urban areas. It also had the credibility to partner with international funders. In the period after the genocide it was one of the most active organizations that created various peace initiatives in communities around the country. For example, UNIFEM and International Alert's awardee Véneranda Nzambazamariya, Pro-femmes's president in the mid-1990s, co-initiated the Peace Action Campaign that was widely successful and recognized in Rwanda and beyond. ${ }^{23}$ In the period that Véneranda (as she was fondly called) led the organization, Pro-femmes trained over 25,000 Abunzi (community mediators), $30 \%$ of who were women responsible for resolving land disputes during Gacaca court proceedings. ${ }^{24}$ Abunzi were traditionally only men, hence this was a significant step in the Rwandan cultural context and a breaking up of patriarchal norms. During preparations for Gacaca courts Pro-femmes provided training to judges and witnesses including women. Furthermore, it engaged women of all backgrounds in peace and leadership issues from 2003 to 2005.

Similar to Véneranda, other women leaders took different approaches to reconcile the Rwandan society. This included, for example, a community activist and the director of Association des femmes, pour le Développement Rural (AFDR) called Beata. AFDR was one of the oldest organizations as it was founded before the genocide in mid-1980. In one of their projects to assist genocide widows in Rwanda's southern province, Beata, a Hutu, visited many rural women, including Tutsi genocide widows. A story by one of the Tutsi widows she visited immediately after the genocide shows the courage that was required for a community activist in rural Rwanda. The survivor recounted Beata's visit to a researcher:

'Then this woman you know her, Beata came here to see me. She was my savior. She's the one who brought me to AFDR. When she first came here, I yelled at her, told her go get out of my house. Seeing her with her Hutu face made me even angrier. She said she couldn't leave me because she 'loved me' (She made a spitting sound.) Love? I didn't know what that was anymore. I had lost my husband, my family everything. For me, love didn't exist anymore. Besides how could a stranger love me? She asked me to tell her what happened, but I didn't say anything'. 25

\footnotetext{
${ }^{23}$ Burnet, Jennie E. (2008) 'Gender balance and the meanings of women in governance in postgenocide Rwanda.' African Affairs, 107(428), pp. 361-386.

${ }^{24}$ Gacaca courts were introduced to deal with genocide crimes and reduce pending genocide cases and clouded prisons. For more on gacaca courts see: Clark, Phil (2010) The Gacaca courts, post-genocide justice and reconciliation in Rwanda: Justice without lawyers (Cambridge University Press)

${ }^{25}$ Burnet (2012)
} 
The survivor continued to recount how Beata would visit and bring her milk and sugar or take her out to get her hair washed and braided. She explained that this made her 'feel human again'. ${ }^{26}$ This is a good example of a peace advocate who took an initiative to visit households where other local women were isolated. Local community activists such as Beata created avenues to bring ordinary women into their communities. Their income generating activities allowed them to reconnect with the rest of the society.

In addition to Pro-femmes and AFDR's leaders there were other initiatives whose focus was on building peace through income-generating activities, like Gahaya Links. Founded by two sisters who are returnees, Janet Nkubana and Joy Ndungutse, the social enterprise opened centers for women to weave the traditional basket of Agaseke and Gahaya exported it globally. Agaseke are baskets that were used traditionally in households. ${ }^{27}$ The weavers use locally resourced fibers, sweet grass, banana leaves, raffia and tea leaves for colour. The craft is typically passed on from grandmother to her female descendants, and requires a lot of time and therefore is best practiced when settled in one place. Furthermore, women often work together for morale and during the process natural conversations and friendships evolve. Leaders of Gahaya Links and other similar women social enterprises such as Peace Basket in Huye district southern Rwanda became central to peacebuilding for a number of reasons. Naturally, their craft required women to come out of loneliness, facilitating conversations amongst what otherwise might have proven to be irreconcilable groups. ${ }^{28}$ The cooperatives have been successful because women participants were able to come together over a shared need of earning an income and rebuilding a sense of community. Over time friendships were restored and barriers of 'the other' were broken. ${ }^{29}$

\section{b. Informal networks}

In addition to the organized interventions there were women activists whose informal initiatives contributed to the rebuilding of their communities. Two examples give insight into the nature of these initiatives. First, ordinary women provided orphans with homes, access to school and other necessary means to grow into adults. Before the genocide, there were only four orphanages around the country. ${ }^{30}$ This number increased dramatically to thirty formally registered

\footnotetext{
${ }^{26}$ Ibid

${ }^{27}$ Gahaya Links Weaving process. See: http://gahayalinks.com/products-development/weaving

${ }^{28}$ Gupea, Ezechiel Sentama (2009), Peacebuilding in Post-Genocide Rwanda: The Role of Cooperatives in the Restoration of Interpersonal Relationships. PhD Thesis, Peace and

Development Research, School of Global Studies, University of Gothenburg, pp.114-115

${ }^{29}$ Ibid

30 Cruddas, Sarah Cruddas (2015), 'Rwanda outgrows its genocide orphanages', $B B C, 12$ March 2015
} 
orphanages with an estimated 3,000 orphans after 1994. ${ }^{31}$ However, the number was significantly smaller than the 75,000 orphans in Rwanda at the time because many Rwandans and especially women informally adopted their relatives' orphaned children or took strangers in their homes. Their initiatives with the young generation included talking to them about the history of violence in Rwanda and the importance of reconciliation.

Second, women were also instrumental in building relationships among new neighbors to re-establish trust that was necessary for difficult conversations and empathy towards one another. In the former Kibungo prefecture Rulinda, an officer in charge of resettlement explained that usually relations amongst new neighbors were tense. However, he explained that women were the first to engage in activities of reconciliation. He asserted, for example, that through conversations between women from opposing groups 'trust and harmony was gradually established through women talking'. Furthermore, women were 'persuading their husbands to be more tolerant.' He further explained that simple gestures and cultural practices such as borrowing salt from your neighbor or sharing water facilitated conversations and eventually led to women's farming cooperatives or groups. Through these ad hoc initiatives, men's conversations emerged gradually as women pulled families and communities together. ${ }^{32}$

\section{c. The national policy makers}

Among new women policy makers in Rwanda there are key women who had played significant and visible roles for decades and influenced Rwanda's postgenocide government's peace agenda. A good example is the late Senator Aloys Inyumba. In the early 1990s, Senator Inyumba was one of the key decision makers in the RPF and continued to be influential in the post-genocide government. Inyumba had earned respect within the RPF for raising financial support for the RPA in the 1990s from among the Rwandan diaspora. As a Senator, she represented women's interests on a policy level and regularly engaged with grassroots local leaders and women engaged in peacebuilding activities, and advocated for them on the national level. Among her various achievements is among her various achievements is her championing and ensuring the realisation of the Rwanda National Action Plan (2009-2012) to implement UN resolution 1325 that provided a policy framework for Rwanda and other countries to increase participation of women in peace and security issues. She was part of a

\footnotetext{
31 Ibid

32 Mutamba, John and Izabiliza, Jeanne (2007) 'The Role of Women in Reconciliation and Peace Building in Rwanda Ten Years after Genocide: 1994-2004; Contributions, Challenges and Way Forward.' JENdA: A Journal of Culture and African Women Studies 10, p. 26
} 
small cohort of Rwandan women who successfully made her voice heard in influencing the UN and the post-genocide Rwanda. ${ }^{33}$

In her role as a policy maker she spearheaded efforts to have women involved in peace and security issues in Rwanda. This resulted in the inclusion of Rwandan policewomen in peacekeeping and peacebuilding missions outside Rwanda. As one of the two influential women in RPF, Senator Inyumba's influential voice created a space for other women leaders to engage at the policy level. Hence, the Rwandan Parliament had $61.3 \%$ women representatives according to the InterParliamentary Union's statistics in $2011 .^{34}$ This can be compared to neighboring Burundi, for example, where $17 \%$ of women work in the public sector compared to $83 \%$ men, and women comprise $34 \%$ of parliament. ${ }^{35}$ Liberia is reported to have $12 \%$ of women representatives in Parliament, Uganda has $34 \%$ and both Chad and Ghana are at $12 \%$ of women parliament representatives. ${ }^{36}$ In Rwanda the number of women involved parliament and in public policy and shaping society is growing. ${ }^{37}$

In addition, women leaders have been elected or appointed and participated in local peacebuilding initiatives as mayors, vice mayors, local government leaders or executives, and are allowed to contest for and occupy any level of leadership in Rwanda. For example, in 2011 elections the average was $43.20 \%$ of women in local government and in top management of local government an average of $36.56 \%{ }^{38}$

However, as it is with many post-conflict societies, building peace in Rwanda was not an easy task as a number of factors complicated these efforts to bring women and the larger community together especially at the grassroots level. Beyond overcoming patriarchal social barriers and the need to prove women are able leaders and can tackle complex social issues, there were many other challenges that impeded their efforts. These included staffing issues and their peace agenda if they were incompatible with those of the government.

First, women who were in the grassroots, were very energized and had built local forums got more rewarding often urban careers, and left their local area without

\footnotetext{
${ }^{33}$ James Karuhanga, 'Sen. Inyumba addressed UN Security Council' October $28^{\text {th }} 2011$ New Times, Kigali Rwanda

${ }^{34}$ Women in National Parliaments Report, statistics (last updated on 1 ${ }^{\text {st }}$ July 2017)

35 See: Burundi, U. N. (2006) ,'Burundi and Women's Political Participation-the Role of ONUB.'

36 Inter-Parliamentary Union, (2008), 'Women in parliament.' Report

${ }^{37}$ For an in-depth analysis of Rwandan women participation in society and policies to empower their participation see report of Africa Development Bank of November 2008 titled: 'Rwanda, Gender Assessment: Progress towards improving Women's economic status".

38 Republic of Rwanda (2013), Local Democracy and Local Governance: Benchmarking Rwanda Against the Aberdeen Principles. Kigali: Ministry of Local Government. Table on p.31
} 
having mentored a younger generation of leaders. For example, the local women who had started AFDR left the organizations as soon as the 2003 constitution created quotas for women leaders on national and regional levels. Many left to become mayors, ministers, deputies and local government coordinators. ${ }^{39}$ This inevitably crippled their efforts and as in the case of the AFDR, the less trained activists and organizations lost credibility. Other female activists in organizations gained visibility due to their peacebuilding work and as a result found new career opportunities, access to university education and/or became entrepreneurs, leaving little time for them to engage in less financially rewarding peacebuilding work. ${ }^{40}$

Secondly, local government representatives and security agencies question female community workers about their peace agenda if they worked against the government's reconstruction agenda. ${ }^{41}$ This started between 1994-2002 when there were different political groups emerging, the new government was still vulnerable to insurgency attacks from the Democratic Republic of Congo and had not stabilized or articulated its vision for the country. Hence, peacebuilding work was used sometimes as cover for political activities, which complicated the process of identifying non-political peace builders who were equally important to build peaceful coexistence. As such, women leaders had to devise strategies to engage in peacebuilding work at all levels without threatening the government. Research shows that, women in various countries in Africa started 'using the state' rather than 'resisting it'. ${ }^{42}$ Thus Rwandan female leaders in different sectors of society succeeded at 'using the state' in some of their work. Although some, such as Ingabire Victoire, an opposition figure who returned to campaign for office of the president in 2010 elections, was rejected all together by the government and was instead charged with genocide denialism and eventually imprisoned. ${ }^{43}$

\section{Outcomes for Rwandan society}

As a result of majority representation, for example, Rwandan female leaders in parliament ensured change of legislation that transformed the entire society's perception of women and brought change in post-genocide Rwandan society. For

\footnotetext{
${ }^{39}$ See: Burnet, Jennie E. (2008),'Gender balance and the meanings of women in governance in post-genocide Rwanda.' African Affairs, 107(428) pp. 361-386.

40 There were a lot of funds channelled through women's organizations in 1990's but not for individual salaries. Ibid

41 Burnet, (2012), p192

${ }^{42}$ Gretchen Bauer, and Hannah Evelyn Britton, eds. (2006), Women in African parliaments.

(Boulder, CO: Lynne Rienner Publishers), p.19.

43 This article summarizes how Victoire Ingabire was viewed by the elites in Rwanda: Muheto, Felix. (2010),'Attempt Victoire Ingabire Umuhoza to Rally Genocide Convicts as Cadres of 'Her Revolution'.' The New Times 22.
} 
example, laws have been put in place and implemented for women to inherit land, resolving long-term disputes of land ownership. ${ }^{44}$ In addition, women have equal rights in marriage and divorce laws, which put Rwanda in a very unique position among other African countries.

Furthermore, the changes are reflected at larger societal levels beyond representational politics or government, such as there being more women cooperatives engaged in economic activities. For example, Dukundikawa Coffee cooperative works with women coffee farmers (traditionally reserved for male farmers) and weaving baskets such as the aforementioned Gahaya Links, which employs thousands of rural women. Female participation and leadership is equally evident in leading conversations on reconciliation, justice and peace building at the community level. This was the case when women were voted to be leaders of local Gacaca courts in roles that were traditionally reserved only for men. Survivor Associations such as Ibuka, Association des Veuves du Genocide Agahozo (AVEGA) and AERG for younger generations, and Association des Étudiants et e élèves rescapes du Génocide 45 (AERG) have facilitated conversations on sensitive topics that have resulted in reuniting widows and orphans with their communities.

Despite the positive outcomes, there is evolving research critical of Rwanda's post-genocide women gender equality progress. One scholar, for example, has argued that the laws that were passed such as the land inheritance law was 'spotty affirmation of women's rights. ${ }^{46}$ Similarly, scholars such as Marie Berry,47 Jannie Burnet $^{48}$ and Mageza Barthel ${ }^{49}$ argue that the post-genocide gender equality has benefited only elite and urban women and very little has changed for rural women. Substantial challenges also remain like domestic violence and sexual intimate partner violence according to the UN women global database.

\footnotetext{
44 Uwayezu, Ernest and Mugiraneza, Theodomire (2011), 'Land Policy Reform in Rwanda and Land Tenure Security for all Citizens: Provision and Recognition of Women's Rights over Land.' Gender Issues in Land Administration, paper, no. 4914. Available at: http://www.fig.net/pub/fig2011/papers/ts04g/ts04g uwayezu mugiraneza 4914.pdf..[ Accessed 26 June 2013].

45 Genocide Survivors Students Association

46 Mageza-Barthel (2015), p. 142

47 Berry, Marie E. (2015), 'When 'Bright Futures' Fade: Paradoxes of Women's Empowerment in Rwanda.' Signs: Journal of Women in Culture and Society, 41(1), pp. 1-27

${ }^{48}$ Burnet, Jennie E. (2011),'Women have found respect: Gender quotas, symbolic representation, and female empowerment in Rwanda', Politics \& Gender, 7(3), pp. 303-334

${ }^{49}$ Mageza-Barthel (2015)
} 


\section{Conclusion}

It is argued that leadership is a process that involves a leader having a relationship with followers. In the process of change, participants work towards a common group goal in a particular situation. In Rwanda's case, the realities of the followers' - who in the post-genocide context were mostly women, due to the number of male casualties - informed the kind of laws that were necessary, which were ultimately created. At the same time, leaders influenced their implementation and the changes within Rwandan society. In this case leadership was effective not because of one person or by building institutions, but because of transformation occurring on the individual level, through the relationships that were developed and the peaceful relations that were established in the process to coexist.

Rwanda's case reveals that effective leadership that brings change is a process, and occurs at different levels of society. Small cohorts of female community activists in Rwanda emerged out of a situation of civil war and post-genocide that had left them as widows, young orphans, refugees or as returnees. The conversations and ideas that brought change in Rwanda were generated locally and they were in response to a situation in rural and urban Rwanda. Foreign scholars studying Rwanda have often argued that one person, President Paul Kagame leads post-genocide Rwanda. But while his influence cannot be denied, in Rwanda's post-genocide leadership he did not generate all ideas. This assumption negates and denies agency to other Rwandans who have sacrificed and contributed to post-genocide reconstruction including Rwandan women. There were different agents acting individually and collectively, and individual leaders and ordinary Rwandans who emerged in responding to particular situations at the community level. It is these ideas that then transcended the local community and were eventually scaled up to influencing and changing national policy and often (arguably rightly so) coopted and implemented by the RPF and President Paul Kagame. This demonstrated that leadership can take place as a result of relationships between leaders and ordinary people at different levels of interaction.

Like female leaders' emergence, Rwandans endorsed Gacaca Courts on all levels of society as a response to their crisis. This allowed different kinds of peacebuilding projects to emerge that were unique to the Rwandan situation. Thus, these solutions were locally tailored and devised by the same communities that wanted to restore peace. The case of Rwanda reveals that when local solutions are found to deal with crises, leadership clusters emerge. The state leadership was successful in mobilizing followers around one vision, a set of goals through which the participation of different leaders could take pace. Thus, the different clusters of leadership, either parallel or comprehensive, influenced how peacebuilding projects like Gacaca were perceived, then accepted, and finally implemented. The 
clear projection and goals stated in vision 2020 allowed both ordinary Rwandans and their leaders to have common direction towards rebuilding Rwanda, and allowed them to create spaces for difficult conversations. The case of Rwanda therefore illustrates the close connection between leadership and peacebuilding in post-conflict countries.

Although there is progress in Rwanda, this does not mean that women's rights or society norms have completely altered. Rwandan women still face many challenges in their daily lives such as domestic violence and in rural areas lack of access to micro-loans. There are also men who hold on to traditional beliefs and resist change by undermining female leaders in their public realms or by undermining them in their homes. Hence, the new generation has new challenges to deal with and must strengthen existing laws by building on the good foundation and framework already established.

*David Mwambari is an FWO postdoctoral research fellow at the Department of Conflict and Development Studies at Ghent University in Belgium and an adjunct faculty at The African Leadership Centre (ALC) in the Faculty of Social Science \& Public Policy at King's College London (UK).

\section{BIBLIOGRAPHY}

Abbott, Pamela, and Rucogoza, Marklin (2011), Legal and Policy Framework for Gender Equality and the Empowerment of Women in Rwanda, Institute of Policy Analysis and Research - Rwanda

Bauer, Gretchen, and Britton, E. Hannah (eds.) (2006), Women in African parliaments. (Boulder, CO: Lynne Rienner Publishers)

Berry, Marie E. (2015), 'When 'Bright Futures' Fade: Paradoxes of Women's Empowerment in Rwanda.' Signs: Journal of Women in Culture and Society 41(1), pp. $1-27$

Burnet, Jennie E. (2012), Genocide lives in us: Women, memory, and silence in Rwanda (University of Wisconsin Press)

Burnet, Jennie E. (2011), 'Women have found respect: Gender quotas, symbolic representation, and female empowerment in Rwanda.' Politics \& Gender, 7(3) pp. 303-334

Burnet, Jennie E. (2008), 'Gender balance and the meanings of women in governance in post-genocide Rwanda.' African Affairs, 107(428), pp. 361-386 
Burundi, U. N. (2006), 'Burundi and Women's Political Participation—the Role of ONUB.'

Clark, Phil (2010), The Gacaca courts, post-genocide justice and reconciliation in Rwanda: Justice without lawyers (Cambridge University Press)

Cruddas, Sarah (2015),'Rwanda outgrows its genocide orphanages' BBC.

Available at http://www.bbc.com/news/world-africa-31830220(Accessed 10 September 2016]

Desforges, Alison (1999), 'Leave None to Tell the Story: Genocide in Rwanda.' Human Rights Watch

El- Bushra, Judy and Mukarubuga, Cecile (1995), 'Women, War and Transition.' Genderanddevelopment, 3(3), pp.16-22. Available at, http://www.jstor.org/stable/4030380. [Accessed 25 May 2013]

Goetz, Anne Marie and Hassim, Shireen (eds.) (2003), No Shortcuts to Power: African women in politics and policy making (London: Zed Books)

Gourevitch, Philip (1995), 'After the Genocide: When a people murders up to a million fellow-countrymen, what does it mean to survive?' New Yorker, 18 December 1995

Hollander, Edwin, and Julian James (1968), Contemporary trends in the analysis of leadership processes. No. TR-10. State University of New York Buffalo Department of Psychology.

Inter-Parliamentary Union (2008), 'Women in parliament.' Report.

Jones, Adam (2002), 'Gender and Genocide in Rwanda', Journal of Genocide Research 1(4), pp. 65-94

Kinzer, Stephen (2009), A thousand hills: Rwanda's rebirth and the man who dreamed it (Wiley)

Kotter, John P. (2001) ,'What leaders really do', Harvard Business Review 79(11) pp. 85-98.5

Leftwich, Adrian (2009), 'Bringing agency back in: politics and human agency in building institutions and states', Synthesis and Overview Report of Phase One of The Leaders, Elites and Coalitions Research Programme, Research Paper 6, p.10 
Lorch, Donatella (1994), 'Refugees flee into Tanzania from Rwanda'. The New York Times, last modified May, 1,1994. Available at:

http://www.nytimes.com/1994/05/01/world/refugees-flee-into-tanzaniafrom-rwanda.html (Accessed 10 February 2010)

Macauley, Cameron (2015), 'Women After the Rwandan Genocide: Making the Most of Survival.' Journal of Conventional Weapons Destruction, 17(1)

Mageza-Barthel, Rirhandu (2015), Mobilizing transnational gender politics in post-genocide Rwanda (Ashgate Publishing, Ltd)

Mahmood, Mamdani (2001), 'When Victims Become Killers: Colonialism,' Nativism and the Genocide in Rwanda

Muheto, Felix (2010), 'Attempt Victoire Ingabire Umuhoza to Rally Genocide Convicts as Cadres of 'Her Revolution', The New Times 22

Mutamba, John and Izabiliza Jeanne (2010), 'The Role of Women in Reconciliation and Peace Building in Rwanda Ten Years after Genocide: 19942004; Contributions, Challenges and Way Forward.' JENdA: A Journal of Culture and African Women Studies 10

Newbury, Catharine and Baldwin, Hannah (2001), 'Confronting the Aftermath of Conflict: Women's Organizations in Post-Genocide Rwanda,' Women and Civil War: Impact, Organizations and Action, pp.97-129

Nowrojee, Binaifer. Thomas, Dorothy and Fleischman, Janet (1996), Shattered lives: Sexual violence during the Rwandan genocide and its aftermath. Human Rights Watch, 3169(164)

Uvin, Peter (2002), 'On Counting, Categorizing, and Violence in Burundi and Rwanda' in David I Kertzer and Dominique Arel, Census and Identity: The Politics of Race, Ethnicity, and Language in National Censuses (Cambridge: Cambridge University Press)

Prentice W.C.H. (Jan, 2004), 'Understanding Leadership', Harvard Business Review, pp. 1-8

Prunier, Gérard (1995), The Rwanda crisis: History of a genocide. (Columbia University Press) 
Republic of Rwanda (2013) Local Democracy and Local Governance:

Benchmarking Rwanda Against the Aberdeen Principles (Kigali: Ministry of Local Government)

Rwanda Development Board. 'Doing Business 2012 report: Rwanda $3^{\text {rd }}$ easiest place to do business in Africa and $2^{\text {nd }}$ five year top global reformer'. Available at http://www.rdb.rw/media-centre/press-releases/doing-business-2012-reportrwanda-3rd-easiest-place-to-do-business-in-africa-and-2nd-five-year-topglobal-reformer.html (Accessed 27 May 2013)

Sentama, Ezechiel (2009), 'Peace building in Post-Genocide Rwanda: The Role of Cooperatives in the Restoration of Interpersonal Relationships' PhD Thesis, Peace and Development Research, School of Global Studies, University of Gothenburg

Sharlach, Lisa (1999), 'Gender and genocide in Rwanda: Women as agents and objects of Genocide 1.' Journal of Genocide Research 1(3), pp.387-399.

Tripp, Aili Mari (1998), 'Expanding 'Civil Society': Women and Political Space in Contemporary Uganda', Commonwealth and Comparative Politics, 36(2), pp. 84107.

Uwayezu, Ernest, and Mugiraneza, Theodomir (2011), 'Land Policy Reform in Rwanda and Land Tenure Security for all Citizens: Provision and Recognition of Women's Rights over Land.' Gender Issues in Land Administration, paper no. 4914. Available at:

http://www.fig.net/pub/fig2011/papers/ts04g/ts04g uwayezu mugiraneza 49 14.pdf [Accessed 26 June 2013].

'Vision 2020 and policies'. Available at:

http://www.minecofin.gov.rw/index.php?id=148 [Accessed December 2016]

Wolpe, Howard, and McDonald, Steve., (2006) 'Burundi's Transition: Training Leaders for Peace'. Journal of Democracy, 17(1), pp.126-132 